\title{
Disentangling barrier effects of transport infrastructure: synthesising research for the practice of impact assessment
}

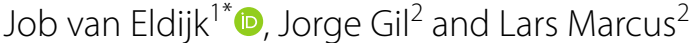

\begin{abstract}
Transport infrastructure such as railways, motorways and arterial roads increases regional accessibility for motorised transport but simultaneously can create barriers in local street networks that can decrease accessibility for pedestrians and cyclists. Although several tools for an objective assessment of these barrier effects have been developed, their use in practice is limited; impact assessments are instead based on subjective descriptions. This article reviews the literature on barrier effects of the last 60 years and aims to offer guidance for the use of objective methods of assessment of barrier effects. The first contribution is a conceptual model for the barrier effects of transport infrastructure and their determinants. The second contribution is an overview of tools for the assessment of barrier effects. We conclude that a multi-disciplinary approach is required, supported by the conceptual model and the overview of assessment tools. Investments in transport infrastructure can then be based on broader decision support involving not only the benefits of increasing regional accessibility but also the cost of reducing local accessibility.
\end{abstract}

Keywords: Barrier effects, Severance, Transport infrastructure, Impact assessment, Accessibility

\section{Introduction}

Transport infrastructure such as motorways, railways and arterial roads can improve accessibility for motorised transport on a regional and inter-urban scale but can at the same time create barriers that reduce accessibility for pedestrians and cyclists on a local scale. These barriers can create detours, reduce opportunities for social contacts, reduce access to workplaces and services, and can make active modes less attractive. Although several indicators and methods have been developed for quantifying the effects of barriers in street networks [3, 40, 104], their application in practice remains limited [8]. Research on barrier effects is also limited compared to other externalities of transport, such as noise and pollution [8].

Instead of objective assessment methods, subjective descriptions are used for the assessment of barrier effects

${ }^{*}$ Correspondence: job.van.eldijk@ramboll.se

${ }^{1}$ Ramboll Sweden AB, Gothenburg, Sweden

Full list of author information is available at the end of the article
[8], making it difficult to include in the overall assessment of transport infrastructure projects, and risking inconsistent estimation of barrier effects. This in turn may negatively affect trust between stakeholders, create social and political controversy, and cause delays to infrastructure projects [46]. Further, it creates the risk of poor and incomplete decision support concerning project alternatives, route alignments and design, which can prevent barrier effects from being solved. Incomplete and subjective assessments of barrier effects can lead to a situation where the mitigation measures turn out to be ineffective in practice or even aggravate the barrier problem [67].

Several reasons have been suggested for the limited research attention to barrier effects of transport infrastructure and the limited use of methods for their assessment in practice. The problem is described as very complex [67, 129] as it is difficult to separate barrier effects from other impacts [14]. The dissemination of knowledge of barrier effects is limited because some of the work is hidden in technical reports commissioned by public administrations 
and not indexed in academic databases [8], and is published in other languages than English.

In response, this review aims to disentangle the many factors involved in barrier effects by (1) synthesising the existing research into a simplified conceptual model of barrier effects of transport infrastructure and (2) presenting an overview of the indicators and methods that have been developed for their assessment. Further, we propose that the objective assessment of barrier effects in all its forms require a wide range of methods, techniques and indicators, rather than a single assessment method as is suggested by the reviews of Marsh and Watts [97] and Quigley and Thornley [116] and Tate.

After this introduction follows the presentation of the review methodology in section "Review methodology", and section "A conceptual model of barrier effects of transport infrastructure" offers a conceptual model for disentangling and understanding the barrier effects of transport infrastructure. Section "What are the determinants of the barrier effects of transport infrastructure?" includes a description of their determinants and in section "What are the barrier effects of transport infrastructure?" a description of the different levels of barrier effects. Section "Which tools have been developed for assessing barrier effects of transport infrastructure?" provides an overview of the indicators that have been developed for the assessment of barrier effects. The conclusion presents a reflection on the conceptual model and the assessment tools presented in the article and their implications for practice and theory.

\section{Review methodology}

\subsection{Search and selection process}

The literature searches for the review were conducted in March 2019 and complemented with an additional search in September 2020. The databases that were searched were TRID, Scopus and Web of Science. TRID was chosen as it is the largest online database for transport literature. Scopus and Web of Science were added as resources because of their extensiveness.

The following search query was used: (severance OR "barrier effect"*) AND (transport" OR traffic OR highway" OR motorway* OR freeway* OR rail*). No limit was set for the year of publication. The search included all kinds of publications, such as journals and conference proceedings, research reports, governmental guidelines and books. From the search results $(n=2267)$, duplicate publications and publications not related to transport or to impacts on people were excluded by reading titles and abstracts, reducing the list to 142 publications. Through searches based on the reference lists of these publications, discussions with experts, and broad searches in Google Scholar an additional 169 relevant publications were found, resulting in a total of 311 publications. Of these, 35 publications could not be retrieved, and nine were written in languages not spoken by the authors. This resulted in a final list of 267 publications, the earliest from 1961 and the most recent from 2021.

The fact that more than half of the relevant literature was not indexed in some of the largest research databases, or could not be found using general search terms, demonstrates the difficulty of getting access to material related to barrier effects. The use of English search terms to some extent limited the coverage of the literature, as this excluded research published in other languages or publications without an English abstract. 75 percent of the publications are academic articles, theses and books, 25 percent are technical reports, guidelines, policy documents and newspaper articles.

\subsection{Scope and terminology}

In the literature, the term 'severance' is frequently used to describe barrier effects of traffic and infrastructure, often in combination with a specification: community severance, physical severance, social severance, secondary severance or psychological severance. There appears not to exist any consensus about the definition of the term, as a review of 60 different definitions shows [4]. Further, the term presupposes the existence of a community before the introduction of a barrier, and it is also used to denote the relocation of residents and businesses for an infrastructure project, but in that case without involving a barrier [61]. The general public has been found to often conflate severance with other nuisances such as noise, pollution and perceived danger [37, $67,75]$. In some studies the term 'encroachment' is used $[56,77]$, which is a broad concept, including land taken for transport, visual intrusion, reduction of the usability of areas near the infrastructure due to emissions and noise, risk of accidents, and negative impacts on wildlife, as well as barrier effects. To avoid confusion, and the risk that the use of specialised terms diverts attention from more important issues [5], the term 'barrier effects' is used in this article.

The concept of 'community cohesion' occupies a central position within the research on barrier effects, as illustrated by the long tradition of the term 'community severance' $[8,28,37,76,116,141]$. Community cohesion is a very broad term also relating to e.g. the values that are shared by people, which creates difficulties in separating barrier effects from other impacts and dimensions of transport in a community. We will use instead the term 'social connectedness', which can be defined as a more precise marker of community coherence [116], and is specifically related to the linkages between people, and between people and places of interaction [46] which can be affected by transport infrastructure.

Barriers created by traffic and infrastructure affect opportunities for movement and contact for wildlife in nature [123]. The majority of publications found in the 
initial phase of the review are related to these impacts. In this article, however, the focus is on impacts on people. Most studies describe impacts on pedestrian and bicycle traffic, but a study by Rajé [117] shows that residential areas can also be isolated by infrastructural and traffic barriers blocking car traffic. Further, the planning and design of motorways can reduce access to adjacent land use for drivers [17]. Therefore, the review is not limited to impacts on pedestrian and bicycle traffic.

Different terms are used in the literature for different categories of modes of transport, such as 'motorised/non-motorised' and 'sedentary/active travel'. With the introduction of e-scooters, e-bikes and motorised wheelchairs the borders between these categorisations have become blurred. Since differences in speed between different modes can be considered a fundamental rationale underlying the design and planning of transport systems and a central reason why barrier effects arise [67], the categorisation proposed in CROW [40] in 'fast and slow modes' is used in the article, unless a specific mode is addressed. The word 'infrastructure' is not only used to denote motorways and railways but also all other constructions built for transport purposes, including roads and tramways.

Publications that refer to barrier effects as an impact of transport or simply include barrier effects in a collection of negative impacts of transport on health, social contacts, use of the street and the environment, without specifying the role of barrier effects, were not included in this article.

\section{A conceptual model of barrier effects of transport infrastructure}

Barrier effects are concomitant effects of transportation systems comparable to noise, pollution and vibration. However, an important difference is that the latter three are emitted from the traffic on the system regardless of its context. In contrast, barrier effects are described as an emerged phenomenon [91] that is determined by several factors; a transport feature becomes a barrier only when it is in the way of someone on their way to somewhere. As a consequence of this multi-factor character, barrier effects cannot be assessed as an isolated externality, but require the engagement of several stakeholders and competences. This creates a need to distinguish firstly, the barrier effects from their determinants, secondly, the relations between different determinants, and thirdly, the different levels of barrier effects. To disentangle these aspects, Fig. 1 presents a conceptual model for the barrier effects of transport infrastructure, describing the determinants and levels of these effects.

Concerning the determinants of barrier effects, following Korner [87], CROW [40], Boon et al. [26] and Anciaes et al. [8], five determinants can be distinguished: (1) transport features, (2) crossing facilities and routes, (3) people's abilities, (4) land use, (5) people's needs. In order to express how the interplay between the determinants results in changes in barrier effects, relations between determinants are here described using mathematical operators. The intention with this notation is to express these relations in a concise way that broadens the perspective on barrier effects from a focus on the transport feature to inclusion of the other four determinants in an equal way. It might be possible to develop the

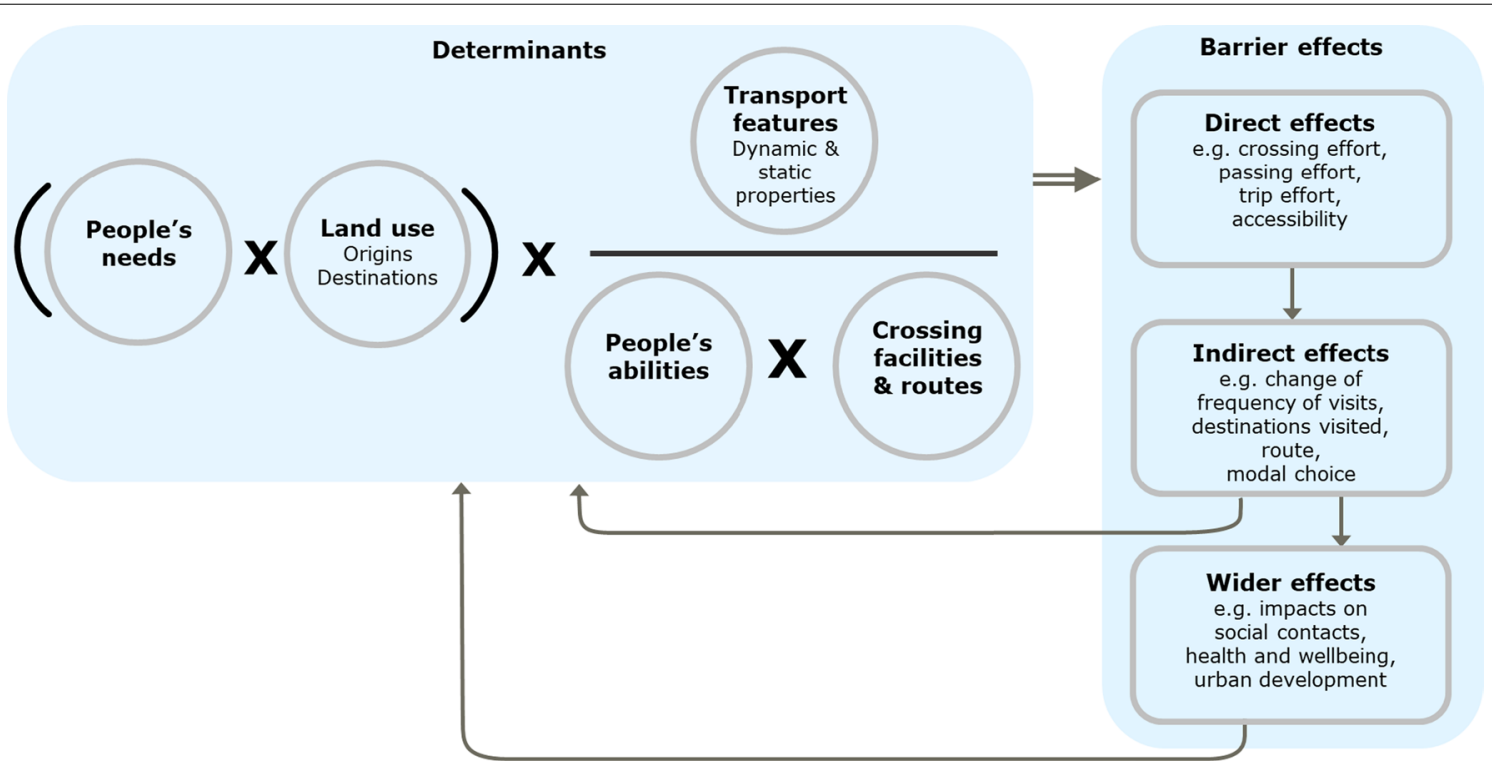

Fig. 1 Conceptual model of the barrier effects of transport infrastructure and traffic 
model further into a mathematical equation, this however requires further investigation and lies outside of the scope of this review.

Some examples can demonstrate the rationale behind the relations between the determinants. Due to the intensity of traffic and the presence of physical barriers, such as fences and noise screens, a transport feature like a road can limit opportunities to cross. Therefore, in the model, an increase in the separation value of 'Transport features' leads to an increase in barrier effects. If a transport feature has no separating characteristics, for example, a footpath in a residential neighbourhood, its separation value is zero and there are no barrier effects, regardless of the values of other determinants. The impact of the separating characteristics of a transport feature can be reduced by the value of the determinant 'Crossing facilities and routes' (such as bridges, tunnels or pedestrian crossings), that create opportunities to cross. These opportunities are further determined through the position of the crossing facilities in the street network and their quality. However, if an individual's ability to cross is limited, due to age or ability, the value of 'People's abilities' is lower and barrier effects increase. For individuals who are unable to cross, the barrier effects of a transport feature become very high, no matter how few separating properties it might have. The determinant 'People's needs' defines the needs of people to reach certain destinations, whereas the determinant 'Land use' defines the need to cross due to the presence and location of destinations. These two determinants combined define the demand to cross the transport feature. For example, if children live on the same side of the railway as their school, they experience no barrier effects of the railway. If the school is relocated on the other side of the railway (a change to the determinant 'Land use'), barrier effects arise. If the number of children in the area decreases (a change to the determinant 'People's needs'), barrier effects are reduced again.

Regarding the levels of barrier effects, most authors make a distinction between direct and indirect effects. Like Mouette and Waisman [108] and Korner [87], we have chosen to further split the indirect effects into indirect and wider effects, as this allows the distinction of different areas of responsibility and competence involved in the assessment process. We therefore categorise barrier effects according to a three-level hierarchy (Fig. 1) where transport behaviour is the distinctive element: (1) direct effects: extra travel efforts that occur when a new transport feature is constructed or when the deterring characteristics of an existing transport feature changes, such as an increase in traffic; (2) Indirect effects: changes in travel behaviour when the extra efforts caused by the barrier pass the acceptance level of the individual; (3) Wider effects: impacts of the changes in travel behaviour on individuals and society at large. The model (Fig. 1) represents the role played by time, both on barrier effects and their relations with the determinants. Barrier effects can create positive and negative feedback loops in the system by impacting the determinants from which they originate [87]. An example of such a feedback loop occurs when a busy road motivates people to drive instead of walk or cycle (indirect effect). This leads to an increase in car traffic on the road (transport features determinant), affecting the crossability or passing effort (direct effect), and can lead to more people choosing to take the car and further increase of barrier effects [67].

\section{What are the determinants of the barrier effects of transport infrastructure?}

\subsection{Transport features}

Transport features are the central determinant in the process of how barrier effects arise. The attention on barrier effects has grown together with the growth in car traffic in cities, and the literature is mainly focused on the determinant role of this mode of transport. However, infrastructural barriers can be defined as all forms of transport infrastructure that reduce or remove opportunities for movement from one location to another, including railways and waterways. Based on Anciaes et al. [8], Héran [65, 67] and Korner [87], Table 1 presents the physical and psychological properties of transport features that determine their barrier effects. Also listed are separating aspects of transport features that depend on formal regulation rather than physical boundaries.

Table 1 follows the distinction between physical and psychological barriers often made in the literature. Sometimes these categories are described as "real" and "perceived" barriers [32, 58], terms that could be interpreted as a value statement. We define physical barriers as objective barriers, related to characteristics that exist without a person being present, and psychological barriers as subjective barriers, related to psychological reactions to the built environment that can vary from person to person and do not occur when no one is present. Psychological aspects of transport features are concerned with conditions that can lead to various psychological reactions (barrier effects of different levels, see section "What are the barrier effects of transport infrastructure?"). For example, the nuisances of traffic, such as risks of accidents, noise, pollution, dust and vibrations, can create a separating effect without physically hindering travel behaviour.

\subsection{Crossing facilities and routes}

The planning and quality of crossing facilities [95, 99] and of crossing routes [40, 67] further determine 
Table 1 Properties of transport features that determine barrier effects

\begin{tabular}{|c|c|c|}
\hline Properties & Type & Description \\
\hline \multicolumn{3}{|l|}{ Physical } \\
\hline Static & $\begin{array}{l}\text { Motorways and feeder roads, } \\
\text { railways, waterways }\end{array}$ & $\begin{array}{l}\text { Fences, railings, noise screens, height differences (embank- } \\
\text { ment, ditches), road width, traffic isles, visual conditions at } \\
\text { crossing points [22] }\end{array}$ \\
\hline \multirow[t]{2}{*}{ Dynamic } & $\begin{array}{l}\text { Transversal, across a feature } \\
\text { (car or tram traffic) }\end{array}$ & $\begin{array}{l}\text { Traffic flow, traffic direction, speed, proportion of heavy } \\
\text { vehicles, parked vehicles [8], bunching of vehicles [57], } \\
\text { waiting time at controlled crossings [87], snow clearing }\end{array}$ \\
\hline & $\begin{array}{l}\text { Longitudinal, along a feature } \\
\text { (car or tram traffic) }\end{array}$ & $\begin{array}{l}\text { Traffic flow, speed, proportion of heavy vehicles, parked } \\
\text { vehicles [67], affecting mostly bicycles }[48,67,87]\end{array}$ \\
\hline \multicolumn{3}{|l|}{ Psychological } \\
\hline \multirow{3}{*}{$\begin{array}{l}\text { Characteristics of transport features and their environ- } \\
\text { ment that have a deterring effect without creating a } \\
\text { physical barrier }\end{array}$} & Conditions for fear of accidents & $\begin{array}{l}\text { Experienced risk of traffic accidents occurring when cross- } \\
\text { ing or travelling along a transport feature }[70,78]\end{array}$ \\
\hline & Conditions for fear of crime & $\begin{array}{l}\text { Lighting, visibility, escape opportunities, social surveillance } \\
{[6,142]}\end{array}$ \\
\hline & Conditions for discomfort & $\begin{array}{l}\text { Noise, pollution [60,92], dust [30], smell, vibrations, } \\
\text { splashes, less attractive routes [40], amount of scrap on and } \\
\text { around crossing facilities [88] }\end{array}$ \\
\hline \multicolumn{3}{|l|}{ Formal } \\
\hline Traffic rules & & $\begin{array}{l}\text { Traffic lights, possibility for manually controlled traffic } \\
\text { lights, one-way streets [87], parental rule that a child is not } \\
\text { allowed to cross a road }[87,130]\end{array}$ \\
\hline Planned infrastructure projects & & $\begin{array}{l}\text { Reserves in land use planning documents can create zones } \\
\text { that form a barrier for transport }[31,43] \text {, uncertainty about } \\
\text { the possible barrier effects of planned infrastructure can } \\
\text { impact land prices and urban development [127] }\end{array}$ \\
\hline
\end{tabular}

opportunities to overcome barriers. Table 2 lists properties that have been identified as determining barrier effects.

The importance of the frequency and location of crossing facilities varies for different modes. For car traffic, travel time is the most defining factor. For slow modes, since they often involve muscle power, distance is a more sensitive parameter, as the numerous shortcuts and 'elephant paths' (informal footpaths trampled over time) in our cities demonstrate [40,67]. These two principles, travel time and travel distance, combined with the need to create safe traffic environments, have led in many cities to the development of two separate traffic networks: one tree-like, hierarchical network for fast modes that allows

Table 2 Properties of crossing facilities and routes that determine barrier effects

\begin{tabular}{|c|c|}
\hline Properties & Description \\
\hline \multicolumn{2}{|l|}{ Crossing facilities } \\
\hline Number of crossing points & Slow mobility modes require a higher number of crossing points than fast mobility modes $[40,67]$ \\
\hline Height differences & Stairs and ramps leading to bridges and tunnels $[6,67]$ \\
\hline Integration in the local street network & Connection to routes or central mobility strips [131] \\
\hline Visual conditions & Lines of sight and overview at crossing points on roads $[22,87]$ \\
\hline Conditions for fear of crime & $\begin{array}{l}\text { Lighting, visibility, escape opportunities, social surveillance }[6,142] \text {. For a further description, see } \\
\text { section "Transport features" }\end{array}$ \\
\hline Quality & Protection from weather, maintenance [6], design and cleanliness [88] \\
\hline Formal regulation & Pedestrian crossings, traffic lights and possibility to manually control these [87] \\
\hline \multicolumn{2}{|l|}{ Crossing routes } \\
\hline Number of crossing routes & Utilitarian and recreational routes for slow mobility that cross the transport feature [40] \\
\hline Connectivity of the street network & Mesh width [40] \\
\hline Density of the street network & Network length per hectare or km² [67] \\
\hline Attractivity & Planning, design, signage, cultural-historic value, level of traffic safety $[6,40]$ \\
\hline
\end{tabular}


for differentiation of speeds in connecting and distributing traffic, and one network for slow modes that is finely gridded and allows for shortcuts [67]. The superposition of these two networks in cities leads to many overlaps (longitudinal) and crossing (transversal) conflicts, the latter solved with different crossing facilities that often require extra effort, detours, or waiting for slow modes.

\subsection{People's abilities}

The actual impacts of the separating characteristics of a transport feature and the availability of crossing facilities and adequate routes are determined by people's abilities, related to both crossing and moving along the actual transport feature, as well as travelling across a larger area that is created for a transport feature and its safety zones. Table 3 lists some of the factors that define people's abilities to overcome barriers.

Age is identified in the literature as the dominant factor for dealing with barriers; besides being listed as a separate factor in Table 3, age is also linked to the other factors listed. Gender is another aspect often mentioned in the literature; related factors are: physical capabilities, limited or no access to a car due to the role in the household, responsibility for accompanying others, and pregnancy. A further example of how gender forms a factor is the way many parents in African cities are reluctant to let their daughters walk along major roads and unsafe paths [30].

Modes of transport determine the possibilities to move across the built environment as they give or restrict access to transport networks and spaces. The studied literature strongly focuses on barrier effects on cyclists and pedestrians, while Rajé [117] demonstrates that car traffic from residential neighbourhoods can also suffer from the barrier effects of busy roads.

\subsection{Land use}

Land use plays a passive role in the location and extent of barrier effects through the spatial distribution [93] and density of both residential addresses and facilities. But land use can also play an active role when the spatial distribution and density of land use changes, which can increase, decrease or relocate potential needs to cross $[3,17,67]$, for example, the expansion of residential areas and the relocalisation of sports clubs or schools to the 'other side' of motorways and railways [40, 67]. Functional separation in cities also contributes to barrier effects by separating residential zones from retail, service and industry zones, which increases travel distances and creates the need to cross the transport infrastructure located between these zones [87] (Table 4).

Table 3 Factors that define people's ability to overcome barriers

\begin{tabular}{|c|c|}
\hline Factor & Description \\
\hline Age & $\begin{array}{l}\text { Sensorial, cognitive and practical constraints of children } \\
\text { and older people }[35,70,103,136]\end{array}$ \\
\hline \multirow[t]{4}{*}{ Mobility restrictions } & Physical and psychological capabilities [67] \\
\hline & Pregnancy $[67]$ \\
\hline & Accompanying others (e.g. pram or wheelchair) $[67,108]$ \\
\hline & Carrying luggage/shopping [67] \\
\hline Mode of transport & Foot, bicycle, public transport, car $[8,117]$ \\
\hline \multirow[t]{3}{*}{ Limited or no access to a car } & Role in the household [67] \\
\hline & Environmental concern $[18,67]$ \\
\hline & Financial restrictions [130] \\
\hline Knowledge restrictions & Awareness of transport options [130] \\
\hline
\end{tabular}

Table 4 Aspects of land use that contribute to barrier effects

\begin{tabular}{ll}
\hline Aspect & Description \\
\hline Distribution & Location of residential addresses and facilities within the area affected by a barrier $[35,67]$ \\
Density & Density of residential addresses and facilities within the area affected by a barrier $[3,42]$ \\
Quality & Differences in the quality of service or products offered on both sides of a barrier $[26]$ \\
Temporal availability & Opening hours of facilities $[26,130]$ \\
Substitutability & Available choice of alternative facilities $[17,130]$ \\
\hline
\end{tabular}


Table 5 Factors that influence people's needs to visit destinations involving trips across or along a barrier

\begin{tabular}{ll}
\hline Factors & Description \\
\hline Age & $\begin{array}{l}\text { Averages of daily trips, e.g. to playgrounds, bus stops, services for different age groups, can be derived from travel surveys } \\
{[48]}\end{array}$ \\
Income, employment, role in the household, lifestyle orientation and preferences [83] leading to restrictions in choice of \\
residential location, workplace, education, shopping [8,67] \\
Social connectedness & $\begin{array}{l}\text { The more a person is dependent on local social contacts, the stronger the need to cross a barrier if these local contacts are } \\
\text { within the neighbourhood } \\
\text { located on the other side [130]. In contrast, more mobile social groups are described as less sensitive to barrier effects [130] }\end{array}$
\end{tabular}

\subsection{People's needs}

While the four determinants described so far all contribute to the potential barrier effects of a transport feature, it is through the needs of people that barrier effects are actualised [126] (Table 5). Actual barrier effects arise only when a person needs to visit a facility on the other side of a road that is too busy for crossing, or when a person is not able to take the stairs of a bridge over that road, or where no crossing facility is provided. The needs to visit social contacts, facilities, services and amenities vary for different groups and individuals. Boon et al. [26] distinguish three general groups of needs: self-fulfilment, social interaction and consumption. Different sets of destinations to fulfil the needs of people have been proposed, such as health, education, services, social, leisure, shops and transport $[37,46]$.

In impact assessments, the focus generally lies on people who are resident in the study area, but as many trips have other starting points than home, the perspective of workers and visitors in the area also needs to be considered $[8,130]$. Barrier effects can also impact business and services in a different way than residents. Losing access to a supermarket will have less of a cost for a resident if a new supermarket is established within reach, however, for a supermarket the loss of customers can have significant consequences [46, 133].

As impacts cannot be assessed for each resident separately, some form of categorisation of groups must be made. Many general categorisations of people have been suggested for the assessment of effects of changes in transport systems $[69,81-83]$, and with a specific focus on groups that are vulnerable to barrier effects (see section "People's abilities") [37, 46, 67, 91, 119]. However, it is likely that different categorisations need to be established for the specific cultural context, type and scale of the project or situation that is being assessed.

\section{What are the barrier effects of transport infrastructure?}

\subsection{Direct barrier effects}

Direct barrier effects (Table 6) are the inconveniences that people experience and sacrifices they must make due to separating 'Transport Features'. The defining characteristic of direct barrier effects is that they occur when people keep their ordinary travel behaviour and accept the inconveniences and sacrifices, either because the level of the barrier effects does not exceed their acceptance level or because there is no alternative. Table 6 lists the direct barrier effects of traffic and transport infrastructure.

Extra effort to cross or pass along a transport feature is the primal direct effect of barriers. Fear of crime, like fear of traffic accidents, is an emotional reaction to the perceived physical and social environment [140] that can create psychological barriers (see section "Transport features"). It is therefore a type of crossing effort. Because of its complexity, it is presented here as an individual effect. Defined by a wide range of factors, on an individual, group as well as environmental level [142], it is typically related to the enclosed spaces of underpasses [6]. It involves both the direct fear of becoming a victim, which can affect travel behaviour during a trip, and anxiety about the risk of becoming a victim, which can lead to long-term changes in travel behaviour.

\subsection{Indirect barrier effects}

Indirect barrier effects comprise the various changes in travel behaviour that occur when direct barrier effects exceed the acceptance level of a person. These behaviour changes can relate to travel frequency, destination, route, time, or transport mode (Table 7). Acceptance levels of individuals are not fixed and can change; consequently, indirect effects can alter over time [91].

The indirect effect of mode of transport can cause a negative feedback loop where a modal shift from walking and cycling to car travel can increase car traffic on roads and increase direct barrier effects $[40,67]$.

\subsection{Wider barrier effects}

Wider barrier effects involve the impacts on individuals, groups and society at large of changed travel behaviour due a barrier. These effects involve many dimensions and aspects and are therefore hard to reduce to a concise list. Instead, we will describe some of the general groups of wider barrier effects found in the literature. 
Table 6 Direct barrier effects of traffic and transport infrastructure

\begin{tabular}{|c|c|}
\hline Effects on & Description \\
\hline Crossing effort & $\begin{array}{l}\text { Delays, physical effort, discomfort, stress, and fear of traffic accidents while crossing a transport feature, due to its static or } \\
\text { dynamic barrier characteristics or the quality, design or planning of crossing routes and facilities (transversal barriers, see } \\
\text { section "Transport features") [6]*,[18], [29], [71]*,[76]* }\end{array}$ \\
\hline Passing effort & $\begin{array}{l}\text { Physical effort, comfort, stress and traffic risks while passing along a traffic feature, affecting cyclists especially (longitudinal } \\
\text { barriers, see section "Transport features"). [67, 87, 104] }\end{array}$ \\
\hline Fear of crime & Fear and anxiety about becoming the victim of crime, typically related to crossing facilities [6]* \\
\hline \multirow[t]{5}{*}{ Trip effort } & $\begin{array}{l}\text { Extra travel time, physical effort, comfort, stress and cost for trips, e.g. to schools, workplace, facilities and social contacts. } \\
{[29]^{*},[31]^{*},[39],[59]^{*},[76]^{*},[107]^{*},[108]^{*}}\end{array}$ \\
\hline & $\begin{array}{l}\text { Detours and delays at level crossings that lead to increased travel time and reduce the reliability of service vehicles such as } \\
\text { mail and waste collection }[38,67,95,111] \text { and public transport [41] }\end{array}$ \\
\hline & Change in the number of routes available to reach a destination $[40,97]$ \\
\hline & $\begin{array}{l}\text { Change of possibilities for drivers to access destinations located adjacent to a road [17], when the road is upgraded to } \\
\text { motorway standard, possibilities to park at the roadside are removed and the number of exits are reduced }\end{array}$ \\
\hline & Travel time between different parts of a farm [20] \\
\hline \multirow[t]{2}{*}{ Accessibility } & Change in the available choice of opportunities within a given travel time or distance [31]*,[40], [50], [108]* \\
\hline & $\begin{array}{l}\text { Change of consumer base of facilities, measured as the change in the number of residents within a certain travel distance } \\
\text { of time from a facility }[17,37,91,130]\end{array}$ \\
\hline
\end{tabular}

${ }^{*}$ Empirically supported effect

Table 7 Indirect barrier effects of traffic and transport infrastructure

\begin{tabular}{|c|c|}
\hline Effects on & Description \\
\hline Frequency of visits & $\begin{array}{l}\text { When trips take more effort due to a barrier, the frequency of visits can change or motivate people to suppress trips all together } \\
{[9]^{*},[71]^{*},[96]^{*},[108]^{*}}\end{array}$ \\
\hline Visited destinations & $\begin{array}{l}\text { Changes in accessibility can motivate people to reorient themselves regarding shops they usually visit, looking for opportunities } \\
\text { that do not involve crossing }[50,62,108]^{*}\end{array}$ \\
\hline Routing of trips & Routing of trips can be changed to avoid barriers [40] \\
\hline Organisation of trips & Timing and organisation of trips can be changed, with people combining different destinations in one trip [59]*, [71]* \\
\hline Mode of transport & $\begin{array}{l}\text { Increased distances or changed levels of traffic safety can make people change mode, typically choosing to drive instead of walk } \\
\text { or cycle to everyday destinations }[47]^{*},[76]^{*},[115]^{*}\end{array}$ \\
\hline
\end{tabular}

* Empirically supported effect

The most prominent wider barrier effect mentioned in nearly all studies and reports is the impact on social contacts and social connectedness. Important studies were carried out in the late $60 \mathrm{~s}, 70 \mathrm{~s}$ and $80 \mathrm{~s}$ by Appleyard and Lintell $[12,13]$, who demonstrated that people living in streets with high levels of traffic had fewer social contacts with their neighbours than people living in streets with less traffic. Also, people living on busy streets indicated that their neighbourhood was smaller than that of residents on lightly trafficked streets. The findings by Appleyard and Lintell had been previously demonstrated by Bryan [34] and have since been confirmed in several studies [27, 63, 86, 98, 125, 135, 143]. A limitation of these studies is that they analyse the combined impact of noise, pollution and traffic risks on social contacts which makes it difficult to isolate the specific impact of traffic as a barrier.
Lee and Tagg [93] studied the impacts of barriers on social contacts specifically, demonstrating that, despite what was expected and contrary to the results of Appleyard and Lintell $[12,13]$, the areas indicated by residents as their neighbourhood were larger in locations near a motorway than comparable locations without a motorway. Neighbourhoods near older motorways were even larger but were found to grow away from the barrier. Fewer trips across the motorway were recorded and residents also had fewer social contacts across the motorway. However, this last effect was found to diminish over time. Further, barriers can force people to choose cars rather than walking or cycling (an indirect effect, see section "People's abilities"), which reduces possibilities for social contacts and social connectedness [29, 76]. The discontinuities caused by barriers reduce the free flow of people on the street network, and can decrease diversity and mingling of people on the streets [73]. 
The second group of wider barrier effects that is often mentioned are impacts on health and wellbeing, even if a direct causal relationship is hard to establish [44, 102]. Negative impacts on health occur due to reduced opportunities for social contacts $[25,103,126]$, for active travel $[25,80,90,102]$, and reduced accessibility to health services, to shops with healthier food products and to facilities for physical activity [25, 39, 102, 103]. Barriers can lead to feelings of being cut off, including missing the passive utility of knowing that the opportunity of access to facilities exists, for example, availability of a hospital, giving a feeling of security [130]. Busy streets can reduce possibilities for children's independent play which has been connected to reduced motor and social skills and independence of children [128], although it is unclear if the reduction in children's play is related to difficulties in crossing streets rather than to noise, pollution and traffic safety. For older people, barriers can lead to restricted freedom of movement, affecting their experience of independence and engagement in social networks, which affects physical and mental health [59, 80, 101, 126].

Barriers also have wider effects on urban development and economic activity that extend over larger temporal and geographical scales. An example are railways and stations, often playing a key role in the historic development process of cities, both attracting and generating movement as well as forming a hindrance to movement [19, 113]. Such infrastructures can disrupt the street network in the vicinity to the station, and lead to a process of degradation and concentration of poverty [23, 24]. This segregating effect of motorways and railways has also been used intentionally for the enforcement of socio-political agendas, as cases in South Africa [30] and in the US [100] demonstrate. Although no causal relations were established, different studies showed cases where barriers like motorways and major roads coincide with boundaries between ethnic groups in the US [110], between vulnerable social groups [85], and between income levels of neighbourhoods [105]. Additionally, the effect of large roads as barrier against crime has been studied, with apparent contradictory results. While some studies show no reduction in crime $[114,118]$, other studies show how roads and other types of barriers do contribute to reducing crime $[16,36,144]$.

On a more local scale, reduced numbers of passers-by in the vicinity of transport infrastructure barriers can increase the fear of crime, and create a negative feedback loop in which more people avoid the area around infrastructure, turning it more desolate. Similarly, barriers can cause a decrease in economic activity [51, 72, 119] and a reduction in the customer base of commercial and public facilities, leading to negative impacts on their capacity and quality $[46,87,133]$. If traffic in a multi-functional street is prioritised over its function as a service centre for the surrounding area, its role as magnet for economic and social activity can disappear, leading to a decline in the number of businesses located there [38, 73, 95]. Outside of urban areas, barriers can fragment recreational areas and recreational road networks $[64,132]$.

\section{Which tools have been developed for assessing barrier effects of transport infrastructure?}

Several tools have been developed for the assessment of barrier effects of transport infrastructure, to be used individually and as part of an assessment method. The following overview is organised on the same three levels as barrier effects. Besides indicators and assessment methods, monetisation techniques have been proposed for the assessment of barrier effects. As these are not connected to a specific effect level, they are presented in a separate subsection.

\subsection{Indicators of direct barrier effects}

The majority of indicators that have been developed deal with direct effects. Table 8 lists the indicators of direct barrier effects found in the literature, categorised according to the effects they relate to.

A central aspect of the trip effort and accessibility indicators is the selection of destinations considered, and different sets of destinations have been proposed [37, 46]. Which destinations are of importance depends on the social and geographic context of the study area, the character and scale of the project, and the issues that are being assessed. It is important to consider that the indicators involving land use give no insight into the actual demands of people [126], that the accessibility needs of people vary, attitudes and reactions from residents can change over time [8], and that changes in transport systems can create conditions for the establishment of new services that replace old ones of lesser quality [46].

A different perspective can also be applied to the assessment, shifting focus from measuring barrier effects of a transport feature to measuring the potential improvements of alternative solutions of new crossing facilities to reduce barrier effects. An example of this can be found in Andersson et al. [11] who assessed locations for a bridge across a river by looking at increase in accessibility to workplaces and travel time savings offered by different alternatives.

\subsection{Indicators of indirect barrier effects}

Table 9 presents the indicators for indirect barrier effects found in the literature. Given that these effects relate to changes in travel behaviour, most indicators are based on surveys and interviews. Russell and Hine [122] emphasise that travel behaviour is based on subjective perception of 
Table 8 Indicators of direct barrier effects

\begin{tabular}{|c|c|c|c|c|c|c|}
\hline \multirow[t]{2}{*}{ Effect on } & \multirow[t]{2}{*}{ Indicator } & \multirow[t]{2}{*}{ Description } & \multicolumn{4}{|l|}{ Technique } \\
\hline & & & $\begin{array}{l}\text { Video } \\
\text { observation } \\
\text { and traffic } \\
\text { counting }\end{array}$ & Site audits & $\begin{array}{l}\text { Surveys } \\
\text { and } \\
\text { interviews }\end{array}$ & $\begin{array}{l}\text { Geospatial } \\
\text { analysis } \\
s\end{array}$ \\
\hline \multirow[t]{7}{*}{$\begin{array}{l}\text { Crossing effort (static } \\
\text { characteristics) }\end{array}$} & $\begin{array}{l}\text { Localisation of transport infra- } \\
\text { structure }\end{array}$ & {$[21,40,87]$} & & & & $x$ \\
\hline & Road width & Road width that needs to be crossed in meters $[21,40,87]$ & & $x$ & & $x$ \\
\hline & Number of lanes & {$[21,40,87]$} & & $x$ & & $x$ \\
\hline & Hindrances along infrastructure & Fences, noise screens, etc. $[21,40,87]$ & & $x$ & & $x$ \\
\hline & Width of central reservation & {$[21,40,87]$} & & $x$ & & $x$ \\
\hline & \multicolumn{3}{|c|}{ Visual conditions at crossing facility Lines of sight at the crossing facility $[21,40,87]$} & $x$ & & $x$ \\
\hline & Height differences & $\begin{array}{l}\text { Bank on which the transport feature is located or if the feature } \\
\text { is placed in a trench }[21,40,87]\end{array}$ & & $x$ & & $x$ \\
\hline \multirow{7}{*}{$\begin{array}{l}\text { Crossing effort (dynamic } \\
\text { characteristics) }\end{array}$} & Speed & km per hour $[40,99,122]$ & $x$ & & & \\
\hline & Volume & Vehicles per hour $[40,99,122]$ & $x$ & & & \\
\hline & Vehicle composition & $\begin{array}{l}\text { Proportion of heavy vehicles (trucks, busses) in the total traffic } X \\
\text { flow }[40,99,122]\end{array}$ & & & & \\
\hline & Direction of traffic & Left/right $[40,99,122]$ & & $x$ & & $x$ \\
\hline & Distribution of acceptance gaps & $\begin{array}{l}\text { Related to the grouping of passing vehicles, measured by } \\
\text { adding reaction time, crossing time and a safety margin. It } \\
\text { must be considered that different social groups (e.g. age } \\
\text { groups) have different reaction times, crossing times and } \\
\text { safety margins. }[57,58,122]\end{array}$ & $x$ & & $x$ & \\
\hline & Parked vehicles & Number of parked cars along a street $[67,122]$ & & $x$ & & \\
\hline & $\begin{array}{l}\text { Risk of traffic accidents while } \\
\text { crossing }\end{array}$ & Number of traffic accidents on a given stretch or point [99] & $x$ & & & \\
\hline \multirow[t]{4}{*}{ Crossing effort (facilities) } & Distance to a crossing facility & $\begin{array}{l}\text { Distance between a street connection with the barrier and } \\
\text { the nearest crossing facility [99] }\end{array}$ & & & $x$ & \\
\hline & Delay at crossing facility & $\begin{array}{l}\text { Waiting time for the next opening of a railway or road cross- } \quad X \\
\text { ing facility or next ferry crossing. Possibility to control traffic } \\
\text { lights manually [40] }\end{array}$ & $x$ & & $x$ & $x$ \\
\hline & $\begin{array}{l}\text { Effort required for use of crossing } \\
\text { facilities }\end{array}$ & $\begin{array}{l}\text { Height difference to be overcome at bridges over and tunnels } \\
\text { under the transport feature [67] }\end{array}$ & & $x$ & & \\
\hline & $\begin{array}{l}\text { Protection from weather conditions } \\
\text { at the crossing facility }\end{array}$ & $\begin{array}{l}\text { IsRoofs and screens at bridges for shelter from rain and wind } \\
{[6,67,95]}\end{array}$ & & $x$ & & \\
\hline \multirow[t]{4}{*}{ Passing effort } & Volume & Vehicles per hour $[48,67,130]$ & $x$ & & & \\
\hline & Vehicles composition & $\begin{array}{l}\text { Proportion of heavy vehicles (trucks, busses) in the total traffic } X \\
\text { flow }[48,67,130]\end{array}$ & & & & \\
\hline & Frequency of overtaking & Number of vehicles that overtake a cyclist $[48,67,130]$ & $x$ & & & \\
\hline & Speed & km per hour $[48,67,130]$ & $x$ & & & \\
\hline \multirow[t]{3}{*}{ Fear of crime } & Social surveillance & $\begin{array}{l}\text { Presence of "social eyes" from entrances, windows, passers-by } \\
\text { and surveillance cameras [142] }\end{array}$ & & $x$ & & \\
\hline & Escape options & Number of alternatives for exiting the crossing facility [142] & & $x$ & & \\
\hline & Visual conditions & $\begin{array}{l}\text { Level of lighting in and around the crossing facility and area } \\
\text { around the transport feature. Possibilities for an overview } \\
\text { [142] }\end{array}$ & & $x$ & & \\
\hline \multicolumn{7}{|l|}{ Trip effort } \\
\hline & \multicolumn{3}{|c|}{$\begin{array}{l}\text { Distance between crossing facilities Distance between crossing points; benchmarks: within urban } \\
\qquad \text { environment } \max 300-500 \mathrm{~m} \text {, outside urban environments } \\
\qquad \max 1,000-1,500 \mathrm{~m}[6,9,40,67]\end{array}$} & & & $x$ \\
\hline & Distribution of crossing facilities & Number of crossing facilities per $\mathrm{km}$ along the barrier [40] & & & & $x$ \\
\hline & Number of barriers along routes & $\begin{array}{l}\text { Number of barriers along existing slow mobility routes } \\
\text { (utilitarian and recreational) weighted by e.g. attractiveness, } \\
\text { presence of signage and its cultural heritage value }[40,64 \text {, } \\
67,132]\end{array}$ & & & & $x$ \\
\hline & Number of disconnected streets & $\begin{array}{l}\text { Number of streets that are not connected due to the pres- } \\
\text { ence of a railway station and railway [120] }\end{array}$ & & & & $x$ \\
\hline
\end{tabular}


Table 8 (continued)

\begin{tabular}{|c|c|c|c|c|c|}
\hline \multirow[t]{2}{*}{ Effect on } & \multirow[t]{2}{*}{ Indicator } & \multirow[t]{2}{*}{ Description } & \multicolumn{3}{|l|}{ Technique } \\
\hline & & & $\begin{array}{l}\text { Video Site audits } \\
\text { observation } \\
\text { and traffic } \\
\text { counting }\end{array}$ & $\begin{array}{l}\text { Surveys } \\
\text { and } \\
\text { interviews }\end{array}$ & $\begin{array}{l}\text { Geospatial } \\
\text { analysis }\end{array}$ \\
\hline & Detour factor & $\begin{array}{l}\text { Ratio of network distance and straight-line distance between } \\
\text { given origins and destinations [40, 66, 67]. Benchmarks for } \\
\text { average detour ratio: 1,15-1,25 in urban areas, 1,3 in regular } \\
\text { grids [67] }\end{array}$ & & & $x$ \\
\hline & Closeness & $\begin{array}{l}\text { Proximity of single street segment to all other street segments } \\
\text { within a given travel distance }[23,42]\end{array}$ & & & $x$ \\
\hline & Betweenness & $\begin{array}{l}\text { Frequency of street segments being part of paths with least } \\
\text { impedance between one street segment and all other street } \\
\text { segments [42] }\end{array}$ & & & $x$ \\
\hline & Isodistance & $\begin{array}{l}\text { Ratio of area reachable with a given street network distance } \\
\text { and area within the same distance measured as straight line } \\
{[67]}\end{array}$ & & & $x$ \\
\hline & Proximity to destinations & $\begin{array}{l}\text { Network distance/travel time/travel cost from each address } \\
\text { point to the nearest facility within a given group of facilities. } \\
\text { Also, the number of households affected by longer travel } \\
\text { distances to a given selection of facilities can be calculated } \\
{[14,15,138]}\end{array}$ & & & $x$ \\
\hline & Travel time for service vehicles & $\begin{array}{l}\text { Travel time for service vehicles such as ambulances, public } \\
\text { transport and waste collection }[41,67,95,138]\end{array}$ & & & $x$ \\
\hline \multirow[t]{7}{*}{ Accessibility } & Catchment areas for facilities & $\begin{array}{l}\text { Number of residents or households within the catchment } \\
\text { area of each facility within a given category of facilities. Catch- } \\
\text { ment areas are measured using network distances and are } \\
\text { defined as overlapping or exclusive areas }[37,138]\end{array}$ & & & $x$ \\
\hline & $\begin{array}{l}\text { Choice/substitutability of destina- } \\
\text { tions }\end{array}$ & $\begin{array}{l}\text { Number of destinations within a given group of destination } \\
\text { that are accessible from each address point within a given } \\
\text { travel time. The effect of the barrier will be lower if more than } \\
\text { one destination is accessible }[50,130,133,138]\end{array}$ & & & $x$ \\
\hline & Accessibility to employment & $\begin{array}{l}\text { Accessibility to job opportunities, measured by number of } \\
\text { jobs or revenue of the workplace, inversely weighted by travel } \\
\text { time }[2,76]\end{array}$ & & & $x$ \\
\hline & Degree of separation & $\begin{array}{l}\text { "Physical severance index" [35]. Distribution of built area (in } \\
\text { sq.m.) and distribution of destinations on both sides of a } \\
\text { barrier, expressed as index values. The barrier effect is highest } \\
\text { when the built areas and destinations are equally divided on } \\
\text { both sides, as this implies the highest level of communica- } \\
\text { tions that can be affected. When the built-up area and activi- } \\
\text { ties are on one side only, the barrier effect is lowest [35] }\end{array}$ & & & $x$ \\
\hline & $\begin{array}{l}\text { Lost population-interaction } \\
\text { potential }\end{array}$ & $\begin{array}{l}\text { Number of potential meetings between residents from dif- } \\
\text { ferent neighbourhoods at a common facility that are affected } \\
\text { by a barrier [3] }\end{array}$ & & & $x$ \\
\hline & Land use connectivity & $\begin{array}{l}\text { Number of barriers that are crossed by straight lines drawn } \\
\text { between neighbourhoods and neighbourhoods or between } \\
\text { neighbourhoods and given destinations }[2,40,46]\end{array}$ & & & $x$ \\
\hline & Access from roads & $\begin{array}{l}\text { Number of exits from a road and travel time for drivers to } \\
\text { reach destinations directly adjacent to the road [17] }\end{array}$ & & & $x$ \\
\hline
\end{tabular}

the physical environment, and argue, like many others [8, $26,109,127]$, for the importance of combining qualitative methods such as surveys and interviews with quantitative methods. Interviews especially are described as an important tool as some responses to barriers, such as avoiding road crossings, are impossible to observe [68].
The measurement of suppressed trips offers a challenge, as these trips do not involve behaviour that can be observed directly [68]. The demands that exist within a population can sometimes be revealed only when new services are established [126]. Tirachini [134] used general statistics of travel behaviour to estimate the probability of trips-not-made. If in a specific geographical 
Table 9 Indicators of indirect barrier effects

\begin{tabular}{|c|c|c|}
\hline Effect on & Indicator & Description \\
\hline \multirow[t]{2}{*}{ Frequency of visits } & $\begin{array}{l}\text { Ratio of changes in number of } \\
\text { visits }\end{array}$ & $\begin{array}{l}\text { Percentage of interviewees who indicate they changed the number of visits they make to destinations and social } \\
\text { contacts or decided not to make some of these trips to avoid a barrier }[9,10,71,108]\end{array}$ \\
\hline & Suppressed pedestrian trips & $\begin{array}{l}\text { Number of trips missing in travel behaviour statistics, relative to averages for comparable places. Missing trips can } \\
\text { be assumed to be suppressed or that a different mode was chosen [134] }\end{array}$ \\
\hline Visited destinations & $\begin{array}{l}\text { Ratio of changes in destination } \\
\text { of trips }\end{array}$ & Percentage of interviewees indicating that they changed the range of destinations they visit [108] \\
\hline \multirow[t]{2}{*}{ Routing of trips } & Crossing ratio & $\begin{array}{l}\text { "[N]umber of pedestrians who cross a road as a proportion of the pedestrian flow, over a given section or at a } \\
\text { specific point" [122]. Registration through video observation }\end{array}$ \\
\hline & Ratio of changed routes & Percentage of interviewees indicating that they changed their route planning $[59,71]$ \\
\hline Organisation of trips & $\begin{array}{l}\text { Ratio of changes in timing and } \\
\text { organisation of trips }\end{array}$ & Percentage of interviewees indicating that they changed their trip timing and organisation [68] \\
\hline Mode of transport & Modal share & $\begin{array}{l}\text { Number of trips that, due to barriers, are made with another than the preferred mode, typically foot and bicycle } \\
{[29,47,71]}\end{array}$ \\
\hline
\end{tabular}

area a certain range of short trips is missing compared to general travel behaviour statistics, it may be assumed that these trips are either suppressed or that a different mode was chosen. The study also estimates the probability of people travelling certain distances, defining a threshold after which the probability that people travel by bicycle or on foot drops. The crossing ratio suggested by Russell and Hine [122] allows for the measurement of effects of changes in dynamic and static characteristics of a road, for example when due to a change in the road network the traffic intensity increases. If fewer people cross a street than in comparable situations, there is a possibility that trips are being rerouted or suppressed. The large variations that exist between the character of different streets presents another challenge for this indicator.

Traffic counting at crossing facilities is a conventional approach for estimating indirect barrier effects and making prognoses regarding changes in crossing behaviour due to changes in transport features. But this approach only considers the characteristics of a transport feature and crossing facilities, and disregards the role that routes, people's abilities, land use and people's needs have in the level of barrier effects, and where they can arise. This can lead to misestimations of barrier effects and incorrect decision support regarding planning and design on new crossing facilities [31]. Another misconception is to compare the number of people using a certain crossing facility with the number of people using the transport feature [67]. As described in section "Crossing facilities and routes", slow mobility networks commonly have a spread-out distribution compared with the concentrated flow of fast mobility networks. For a fair comparison, the flows at crossing facilities should be recorded over a longer stretch of the transport feature and compared with the flow on the transport feature itself [67].

\subsection{Assessment of wider effects}

As described in 5.3, wider effects are generally complex, involve many factors and are often characterised by a development over time. In contrast to direct and indirect effects, few explicit indicators or methods for measuring wider effects have been described in the literature. Their assessment is instead part of broader social impact assessments of transport systems that also include the consequences of other impacts of transport, such as noise and pollution. A central challenge for the assessment of wider barrier effects is that little has been done to translate the concepts from social theory to which they relate, to practical tools for assessment $[50,52]$. An example of this is the concept of 'social community', central to much of the research on barrier effects, yet one that is difficult to define objectively. This can be seen as an instance of the hindrances for including barrier effects in the objective assessment of transport infrastructure projects. Furthermore, it is difficult to aggregate the conclusions from the assessment of different types of wider barrier effects into cohesive decision support, given that these assessments often involve different types of valuation, or different scales and units.

Some approaches and methods for assessing the impacts on social contacts were found in the reviewed literature. Hine and Russell [71] and Ogilvie et al. [112] describe their approaches to performing interviews with residents regarding the social impacts of barriers for example. Similar surveys and interviews, comparing neighbourhoods with and without a motorway as a barrier were undertaken by Lee and Tagg [93]. Risks in these assessment methods are reverse causation (such as, low wellbeing causing people to experience traffic as a barrier instead of the other way round) and residual confounding (such as, poor people with low wellbeing can only afford cheaper apartments that may be located near busy roads) [9]. 
Changes over time in the land use and street networks around station areas have been studied using different techniques for longitudinal morphological analyses [23, $24,113]$. A method for studying correlations between residential locations of different socio-economic groups and barriers in cities is presented by King [84]. Similar studies concerning the correlation between socio-demographic characteristics of residents and the quality of the nearest railway crossing (measured as traffic volume, lighting conditions, width walkway, height differences etc.) were presented by Lara and Rodrigues da Silva [88], who repeated their study in a case of crossings over an urban motorway [89].

\subsection{Monetisation}

A generally accepted way of dealing with the challenges of aggregating the results of different impact assessments into decision support is monetisation, that is, representing all impacts with a unified monetary value. Table 10 lists a range of techniques for the monetisation of barrier effects that have been developed.

These monetisation methods are well established within transport investment appraisals and offer the benefit of making it possible to compare externalities of transport systems that are otherwise impossible to compare. The monetisation techniques, except for those based on estimated values and objective valuations, allow for the judgements of the general public to be included in the decision process instead of being based on expert judgements only.

Some challenges in the application of these methods can be mentioned. Estimated monetary values suffer from the problem of subjectivity [121], which goes against the very motivation for attempts at quantification and monetisation. Hedonic modelling typically does not offer understanding of the motivations behind WTP for housing or real estate. Further, it is difficult to isolate barrier effects from other factors that correlate with it, such as noise. An example is the hedonic study by Kang and Cervero [79], often cited as an example of monetisation of barrier effects. It is not clear if the increases in real estate prices presented in the study are due to the introduction of a park, or the removal of noise and other externalities, or if they are due to the removal of a motorway as a barrier. Depending on the design of the choice modelling or contingent valuation surveys, participants can find it difficult to understand the alternatives offered with regards to distance, time, speed and non-visual stimuli [119]. A more general critique of monetisation techniques is that they can lead to a focus on cost-efficiency of the project, and not on general equity for society, and that there is often a disregard of the link between ability to pay and willingness to pay [137]. However, many of these challenges are not limitations inherent to the monetisation methods but result from the way that they are applied, and different approaches have been proposed for addressing the above challenges e.g. handling equity in monetisation [1].

\section{Conclusion and directions for further research}

The background of this review is the trade-off that typically occurs when the increase in accessibility for motorised modes on a regional and inter-urban scale leads to a decrease in accessibility for pedestrians and cyclists on a local scale. The assessment of these barrier effects of transport infrastructure is rarely based on objective methods even though these methods do exist. The possible reasons that are mentioned for this lack is that the problem of barrier effects is complex, it is difficult to separate barrier effects from other impacts and, the dissemination of the literature on barrier effects is limited. In response to these problems, the goal of this article is to increase the knowledge base concerning barrier effects, which can offer support for practice and research for objective assessments of barrier effects.

\subsection{Contributions to practice and theory}

Based on a broad literature review, we have proposed a conceptual model for barrier effects of transport infrastructure and traffic (Fig. 1) that defines the relationships between the determinants of barrier effects and distinguishes different levels of barrier effects. The determinants of barrier effects are identified as 'Transport features', 'Crossing facilities and routes', 'People's abilities', 'Land use' and 'People's needs'; the effects of barriers are categorised in three levels as 'Direct effects', 'Indirect effects', and 'Wider effects'. Importantly, since effects can influence the determinants, which in turn may create new barrier effects, the two parts of the model may interact in a feedback loop. The model offers the possibility of quickly obtaining an overview of which elements in a given situation need to be taken into consideration when assessing barrier effects.

The review highlights how barrier effects are the result of a chain of events involving characteristics of transport systems, of the built environment, and of people. As a consequence, we conclude that barrier effects cannot be treated as a singular externality of transport but instead require a multidisciplinary approach. A central condition for the collaboration in this multidisciplinary approach is consensus about how different elements and aspects of barrier effects are to be named, and how they relate to each other. The proposed conceptual model can contribute to this collaboration by identifying and relating the different determinants of 
Table 10 Techniques for monetisation of barrier effects

\begin{tabular}{|c|c|c|}
\hline Technique & Examples & References \\
\hline Estimated values & $\begin{array}{l}\text { Using general estimates to assign a monetary value to a barrier } \\
\text { effect }\end{array}$ & Flowerdew and Hammond [49], Monzon et al. [106] \\
\hline \multirow{2}{*}{$\begin{array}{l}\text { Contingent valuation method } \\
\text { (measuring Willingness To Pay } \\
\text { (WTP) for non-market goods } \\
\text { using bidding techniques) }\end{array}$} & Measuring WTP for avoiding a motorway & Grudemo [55], Soguel [128] \\
\hline & Measuring WTP for avoiding a barrier to a recreation area & Grudemo et al. [56] \\
\hline \multirow{4}{*}{$\begin{array}{l}\text { Choice modelling (measuring } \\
\text { preferences or WTP based on } \\
\text { choice experiments involving } \\
\text { different combinations of } \\
\text { characteristics of a barrier) }\end{array}$} & $\begin{array}{l}\text { Measuring WTP for reducing barrier effects of different types } \\
\text { of roads, involving characteristics related to road design, traffic } \\
\text { intensity and crossing facilities }\end{array}$ & Anciaes and Jones [10] \\
\hline & Measuring WTP for reducing barrier effects of roads & Anciaes et al. [6] \\
\hline & $\begin{array}{l}\text { Measuring WTP for removing a barrier between two neigh- } \\
\text { bourhoods, taking into consideration amenity characteristics }\end{array}$ & Grisolía et al. [54] \\
\hline & $\begin{array}{l}\text { Measuring Willingness To Accept a new road that reduces } \\
\text { access to a recreational area, using increased leisure time as a } \\
\text { result of decreased travel time as a payment vehicle }\end{array}$ & Ivehammar [72] \\
\hline $\begin{array}{l}\text { Hedonic modelling (measur- } \\
\text { ing WTP for different attributes } \\
\text { of housing (e.g. view, distance } \\
\text { to station) based on analysis of } \\
\text { house sales) }\end{array}$ & $\begin{array}{l}\text { The impacts on WTP for housing related to reductions in acces- } \\
\text { sibility caused by a motorway }\end{array}$ & Broach et al. [33], Eliasson et al. [45], Ellis [46] \\
\hline \multirow{5}{*}{$\begin{array}{l}\text { Objective valuations (using the } \\
\text { value of related market goods } \\
\text { as proxy for the cost of barrier } \\
\text { effects) }\end{array}$} & $\begin{array}{l}\text { Socio-economic costs (increase in traffic accidents, travel time, } \\
\text { school transport, sick leave, parking costs etc.) when potential } \\
\text { bicycle links are not realised due to barriers }\end{array}$ & Sælensminde [124] \\
\hline & Time spent accompanying children to school & Tate and Mara [129] \\
\hline & Monetisation of delay & Baart and Molenkamp [15], Jarlebring et al. [74] \\
\hline & $\begin{array}{l}\text { Multiplying the total population by the number of seconds of } \\
\text { delay that roads and motorways imply. The resulting time is } \\
\text { multiplied by a monetary value }\end{array}$ & van Essen et al. [139] \\
\hline & $\begin{array}{l}\text { Demand for crossing facilities as a decreasing function of the } \\
\text { generalised cost of crossing (such as time to reach the crossing } \\
\text { facility, effort of crossing) }\end{array}$ & Héran [67] \\
\hline
\end{tabular}

barrier effects in a non-hierarchical way. The model describes how barrier effects can be created by a transport feature and can be multiplied by both the distribution of land use over both sides of the feature as well as by the needs of people to access these land uses. The categorisation of barrier effects in direct, indirect and wider effects can further facilitate this collaboration by highlighting the different roles of different actors in the assessment process.

Further, the literature review has found a number of tools for the assessment of barrier effects, and using the conceptual model these tools were categorised and linked to the different levels of barrier effects that they address. This makes it possible to decide more quickly for which project scale and phase and for which assessment question the different indicators are most relevant. Indicators in the categories Crossing effort (dynamic characteristics) and Passing effort (Table 8) for instance, are not relevant to the assessment of a railway project.

The conceptual model and the listed indicators and methods can facilitate objective assessment of barrier effects, which in turn can enable the engagement of stakeholders such as local communities, who often lack access to the technical competence required to interpret indirect and wider barrier effects. Additionally, a multi-disciplinary and more inclusive approach increases the likeliness that measurements to mitigate barrier effects fulfil their purpose.

\subsection{Further research}

The article opens up several directions for potential further research. First, there is a need to extend the evidence base for barrier effects, as only seven of the twelve direct and indirect barrier effects identified in this review are supported with empirical evidence, and the majority of these studies relates to single cases. Second, further work remains regarding the development of indicators in order to cover all types of barrier effects and allow the assessment of not only the magnitude but also of the significance of barrier effects, which is the point when an effect turns into an impact.

Thirdly, in this article, we have limited the description of wider barrier effects to what has been presented in 
the reviewed literature. But many of these effects relate to topics, such as segregation and urban development, that have been studied extensively by other sciences, for example social sciences. A third direction of research is then, on the one hand, to relate the insights offered in those fields of research to the theories and tools of barrier effects, and on the other, to introduce the case of infrastructural barriers into these fields. The conceptual model offers a framework for enabling these inter-disciplinary research exchanges.

The fourth direction concerns the application of the indicators in practice. Transport infrastructure involves a wide range of construction types, project phases and geographical scales, from national high-speed railways to a pedestrian bridge across a road. Anciaes et al. [8] proposed a scheme how to relate these to different types of techniques and methods for the assessment of barrier effects. Further research is needed to establish how the indicators presented in the current review can be categorised in this or another suitable scheme, which can offer explicit guidance for their use in practice.

Fifthly, due to its multi-faceted character, the assessment of barrier effects can involve a multitude of analyses, which can lead to problems of readability, interpretation fatigue, and loss of overview. Further research is needed to establish how the diversity of analyses can be aggregated into comprehensible and concise decision support.

Sixthly, in the introduction we argue that the current practice of basing assessment of barrier effects on subjective descriptions can have a negative impact on the levels of trust between stakeholders. It would be valuable to study what the model and the indicators can contribute to these collaboration processes, specifically if the objective decision support that they offer can increase levels of trust between stakeholders.

Finally, we also see some theoretical implications emerging from the relation between accessibility and the conceptual model of barrier effects, which cannot be fully developed here. The five determinants of barrier effects in the conceptual model developed in this study can be aligned with the three main elements of accessibility [53]: first, 'People's abilities' and 'Peoples needs' concern the individuals that are 'Agents 'in the model of accessibility; second, 'Land use' relates to the different kinds of 'Attractions' that agents want or need to access; third, 'Transport features' and 'Crossing facilities and routes' represent the 'Impedances' that agents need to overcome to access those attractions. Framed this way, the concept of barrier effects can to some extent be said to describe the inverse of accessibility, in dealing with the effort of reaching, rather than the ease of reaching, as accessibility is described (Cervero 1996, in: [94]). In these terms, the improvement of car infrastructure can be described as commonly being aimed at decreasing the impedance (travel time) for the agents (car drivers) to access certain attractions, and increasing car accessibility. This infrastructure often introduces a barrier in accessibility systems on a local scale, increasing impedance for other modes, for instance walking, to access attractions. Since the general aim for national transport administrations concerns the optimalisation of accessibility for all members in society, it is essential to understand the way accessibility works as an inter-scalar system, where the optimisation of accessibility on one scale can lead to a sub-optimal outcome for another. There is a need for research to capture this interaction, which we hope to have contributed to. With adequate theoretical support, investments in transport infrastructure can be based on broader decision support involving not only the benefits of increasing remote accessibility but also the costs of reducing local accessibility.

\section{Authors' contributions}

JE has preformed the literature review on which the manuscript is based and has written the larger part of the text. JG and LM have supervised the research, contributed to the structure, conceptualization, and reviewed the text. All authors have read and approved the final manuscript.

\section{Funding}

Open access funding provided by Chalmers University of Technology. This work was supported by the Ramboll Foundation (Grant dated 23-12-2015), Ramboll Sweden Ltd (Grant dated 16-05-2016), InfraSweden (Grant number 2019-01150), Trafikverket (Grant Number TRV 2016/10608), and Trafikverket's Skyltfond (Grant Number 2015/84777). The funding organisations have had no involvement in the design of the study or the interpretation of the results.

\section{Declarations}

Competing interests

The authors declare that they have no competing interests.

\section{Author details}

${ }^{1}$ Ramboll Sweden AB, Gothenburg, Sweden. ${ }^{2}$ Department of Architecture and Civil Engineering, Chalmers University of Technology, Gothenburg, Sweden.

Received: 19 April 2021 Accepted: 2 November 2021

Published online: 18 January 2022

\footnotetext{
References

1. Adler, M. D. (2016). Benefit-cost analysis and distributional weights: An overview. Review of Environmental Economics and Policy, 10(2), 264-285. https://doi.org/10.1093/reep/rew005

2. Anciaes, P. (2011). Urban transport, pedestrian mobility and social justice: a GIS analysis of the case of the Lisbon Metropolitan Area. [Dissertation, The London School of Economics and Political Science (LSE)] http://etheses.lse.ac.uk/id/eprint/142

3. Anciaes, P. (2013). Measuring community severance for transport policy and project appraisal. Urban Transport XIX, 130, 559-570. https://doi. org/10.2495/UT130451
} 
4. Anciaes, P. (2015). What do we mean by "Community severance"? Working paper https://www.ucl.ac.uk/street-mobility/docs/ucl_streetmobi lity_paper04.

5. Anciaes, P., Boniface, S., Dhanani, A., Mindell, J., \& Groce, N. (2016). Urban transport and community severance: Linking research and policy to link people and places. Journal of Transport \& Health, 3(3), 268-277. https:// doi.org/10.1016/j.jth.2016.07.006

6. Anciaes, P., \& Jones, P. (2018). Estimating preferences for different types of pedestrian crossing facilities. Transportation Research Part F: Traffic Psychology and Behaviour, 52, 222-237. https://doi.org/10.1016/j.trf.2017. 11.025

7. Anciaes, P., Jones, P., \& Metcalfe, P. J. (2018). A stated preference model to value reductions in community severance caused by roads. Transport Policy, 64, 10-19. https://doi.org/10.1016/j.tranpol.2018.01.007

8. Anciaes, P., Jones, P., \& Mindell, J. (2016). Community severance: Where is it found and at what cost? Transport Reviews, 36(3), 293-317. https:// doi.org/10.1080/01441647.2015.1077286

9. Anciaes, P., Stockton, J., Ortegon, A., \& Scholes, S. (2019). Perceptions of road traffic conditions along with their reported impacts on walking are associated with wellbeing. Travel Behaviour and Society, 15, 14. https://doi.org/10.1016/j.tbs.2019.01.006

10. Anciaes, P., \& Jones, P. (2020). A comprehensive approach for the appraisal of the barrier effect of roads on pedestrians. Transportation Research Part A, 134, 227-250. https://doi.org/10.1016/j.tra.2020.02.003

11. Andersson, L., Natalia, K., \& Iqbal, S. (2017). Nyttoanalys av nya gångoch cykelbroar över Göta älv. Technical report. 3150/16. Trafikkontoret, Göteborg Stad. http://www.dalis.goteborg.se/prod/Intraservice/Namnd handlingar/SamrumPortal.nsf/93ec9160f537fa30c12572aa004b6c1a/ 6b58d2ebe6604810c12581 ef0045579f/\$FILE/434\%20PM\%20Nyttoana lys\%20nya\%20gang\%20och\%20cykelbroar\%20over\%20Gota\%20alv. pdf

12. Appleyard, D., Gerson, M. S. \& Lintell, M. (1981). Livable Streets. University of California Press.

13. Appleyard, D., \& Lintell, M. (1972). The environmental quality of city streets: The residents' viewpoint. Journal of the American Institute of Planners., 38(2), 84-101. https://doi.org/10.1080/01944367208977410

14. Atkins. (2009). Assessing social and distributional impacts in transport scheme appraisal and evaluation-Final Report. Report. Atkins Transport Planning \& Management for the Department for Transport (DfT), London.

15. Baart, M \& Molenkamp, L. (1998). The barrier effect for humans and animals: Directing with social and ecological structures. Pp. 233-52 in Colloquium vervoersplanologisch speurwerk 1998: Sturen met Structuren: bundeling van bijdragen aan het colloquium gehouden te delft, 12 en 13 november 1998. deel 1. Delft, The Netherlands.

16. Baudains, P., Braithwaite, A., \& Johnson, S. D. (2013). Target choice during extreme events: A discrete spatial choice model of the 2011 London Riots. Criminology, 51(2), 251-285. https://doi.org/10.1111/1745-9125. 12004

17. Beca Carter Hollings \& Ferner Ltd. (1998). Monetary Valuation of Intangibles: Literature Review and Pilot Surveys. Report (no. 98). Transfund New Zealand.

18. Bein, P. (1997). Chapter 3: Environmental Impacts. in Monetization of Environmental Impacts of Roads. http://www.geocities.ws/davefergus/ Transportation/3CHAP3.htm

19. Bellet, C. (2009). The introduction of the high speed rail and urban restructuring: The case of Spain. Madrid. Conference paper. https:// www.researchgate.net/publication/236158409_The_introduction_of_ the_high_speed_rail_and_urban_restructuring_the_case_of_Spain_ presented_at_CityFutures_2009_Congress_hold_in_Madrid

20. Boddington, M. A. B., Hearne, A. S., \& Leat, P. M. K. (1978). Motorways and Agriculture Severance. Report. Rural Planning Services Limited.

21. de Boer, E., \& van Haaf, R. (2001). Beoordelingsmethode Barrièrwerking Stedelijke Hoofdwegen. Report. TU Delft.

22. de Boer, E., Hendriks J. \& van der Veen, B. (1984). Beoordelingsmethodiek Barrièrewerking. Report. TU Delft.

23. Bolton, T. (2014). The spatial character of London's railway terminus neighbourhoods. In Proceedings of the 10th international space syntax symposium. UCL.
24. Bolton, T. (2018). Railway terminals and separation: Paddington and Marylebone stations, London. In J. Clark \& N. Wise (Eds.), Urban renewal, community and participation (pp. 125-140). Springer.

25. Boniface, S., Scholes, S., Dhanani, A., Anciaes, P., Vaughan, L., \& Mindell, J. (2015). Is community severance a public health problem? Evidence from the street mobility project's two London case studies. Journal of Transport \& Health 2(2, Supplement):S34-35. doi: 10/gddwr4.

26. Boon, W., van Wee G. P. \& Geurs, K. (2003). Barrièrewerking van Infrastructuur: A2 En Amsterdam-Rijnkanaal Barrière Voor Inwoners van Utrecht-Leidsche Rijn? in Colloquium Vervoersplanologisch Speurwerk 2003: No pay, no queue? Oplossingen voor bereikbaarheidsproblemen in steden.

27. Bosselmann, P., Macdonald, E., \& Kronemeyer, T. (1999). Livable streets revisited. Journal of the American Planning Association, 65(2), 168-180. https://doi.org/10.1080/01944369908976045

28. Bowers, P. H. (1974). Community severance and pedestrian network. In Proceedings of the summer annual meeting: Road design, PTRC/P/109. (pp. 59-118).

29. Bradbury, A., Tomlinson, P. \& Millington, A. (2007). Understanding the evolution of community severance and its consequences on mobility and social cohesion over the past century. In Proceedings of the European transport conference (ETC) 2007 held 17-19 October 2007. Association for European Transport.

30. Bradbury, A. (2014). Understanding Community Severance and Its Impact on Women's Access and Mobility in African Countries - Literature Review. Report. Crown Agents. https://assets.publishing.service.gov.uk/media/ 57a089c440f0b64974000262/Severance-LitReview-AFCAPgen127jv140729.pdf

31. Braddock, M. (1979). Evaluation of the severance effects of a proposed rapid transit corridor. Traffic Engineering \& Control 171-83.

32. Brand, C \& Preston, J. (2002). TEST_Working paper 2: The wider costs and benefits of urban public transport systems. Report. University of Oxford.

33. Broach, J., Dill, J., \& Gliebe, J. (2012). Where do cyclists ride? A route choice model developed with revealed preference GPS data. Transportation Research Part A: Policy and Practice, 46(10), 1730-1740. https://doi. org/10.1016/j.tra.2012.07.005

34. Bryan, R. S. (1951). The street—A social barrier. [Master thesis, Massachusetts Institute of Technology].

35. Casado-Sanz, N., Guirao, B., \& Gálvez-Pérez, D. (2019). Population ageing and rural road accidents: Analysis of accident severity in traffic crashes with older pedestrians on Spanish crosstown roads. Research in Transportation Business \& Management. https://doi.org/10.1016/j.rtbm.2019. 100377

36. Clare, J., Fernandez, J., \& Morgan, F. (2009). Formal evaluation of the impact of barriers and connectors on residential burglars' macro-level offending location choices. Australian \& New Zealand Journal of Criminology, 42(2), 139-158. https://doi.org/10.1375/acri.42.2.139

37. Clark, J. M., Hutton, B. J., Burnett, N., Hathway, A. \& Harrison, A. (1991). The Appraisal of Community Severance. Report. Transport and road research laboratory.

38. Cline, M. G. (1963). Urban freeways and social structure-Some problems and proposals. Highway Research Record, 2, 12-20.

39. Crombie, H. \& Munster, D. (2002). The impact of transport and road traffic speed on health. Report. Health Development Agency.

40. CROW. 2011. Barrièrewerking van Lijninfrastructuur. CROW.

41. Delmonte, E. \& Tong, S. 2008. Investigation into traffic delays at level crossings. Report (PPR377). TRL.

42. Dhanani, A. \& Vaughan, L. (2016). Towards a walkability model for strategic evaluation of policy action and urban active transport interventions. In 48th meeting of the universities' transport study group (UTSG). Universities'Transport Study Group (UTSG).

43. Dixon, L. (1996). Bicycle and pedestrian level-of-service performance measures and standards for congestion management systems. Transportation Research Record: Journal of the Transportation Research Board, 1538, 1-9.

44. Egan, M., Petticrew, M., Ogilvie, D., \& Hamilton, V. (2003). New roads and human health: A systematic review. American Journal of Public Health, 93(9), 1463-1471. https://doi.org/10.2105/AJPH.93.9.1463

45. Eliasson, J., Dillen, J. L., Widell J. \& Association for European Transport (AET). (2002). Measuring intrusion valuations through stated preference 
and hedonic prices - A comparative study. Association for European Transport (AET).

46. Ellis, R., H. (1968). Toward measurement of the community consequences of urban freeways. In Transportation system planning and current census techniques for planning, highway research record. pp. 38-51.

47. Emond, C. R., \& Handy, S. L. (2012). Factors associated with bicycling to high school: Insights from Davis, CA. Journal of Transport Geography, 20(1), 71-79. https://doi.org/10.1016/j.jtrangeo.2011.07.008

48. Fäldner, L. (1987). 7.3 Barrier effects. in 15 E Calculation quide - Investments in roads and streets. Report (Vol. 1986:1E). Borlänge: Swedish National Road Administration

49. Flowerdew, A. D. J., \& Hammond, A. (1973). City roads and the environment. Regional Studies, 7(2), 123-136. https://doi.org/10.1080/09595 237300185111

50. Forkenbrock, D. J., Benshoff, S. \& Weisbrod, G. E. (2001). Assessing the Social and Economic Effects of Transportation Projects. Report (Web Document 31). NCHRP. http://onlinepubs.trb.org/onlinepubs/nchrp/ nchrp_w31.pdf

51. Forkenbrock, D. J. \& Weisbrod, G. E. (2001). Guidebook for Assessing the Social and Economic Effects of Transportation Projects. Technical quidelines. Report (no. 456). NCHRP. http://onlinepubs.trb.org/onlinepubs/ nchrp/nchrp_rpt_456-a.pdf

52. Geurs, K. T., Boon, W., \& van Wee, B. (2009). Social impacts of transport: Literature review and the state of the practice of transport appraisal in the Netherlands and the United Kingdom. Transport Reviews, 29(1), 69-90. https://doi.org/10.1080/01441640802130490

53. Geurs, K. T., \& van Wee, B. (2004). Accessibility evaluation of land-use and transport strategies: Review and research directions. Journal of Transport Geography, 12(2), 127-140. https://doi.org/10.1016/j.jtrangeo. 2003.10.005

54. Grisolía, J. M. López, F. \& de Dios Ortúzar, J. (2015). Burying the highway: The social valuation of community severance and amenity. International Journal of Sustainable Transportation, 9(4), 298-309. https:// doi.org/10.1080/15568318.2013.769038

55. Grudemo, S. (1994). Encroachment Costs of New Roads-A Summary of the Results of CVM and 'for or against' Studies. Report (744A). VTI, Swedish National Road and Transport Research Institute.

56. Grudemo, S., Ivehammar, P. \& Sandström, J. (2002). Beräkningsmodell För Infrastrukturinvesteringars Intrångskostnader. VTI Meddelande (939).

57. Guo, X., Black, J., \& Dunne, M. (2001). Crossing pedestrians and dynamic severance on urban main roads. Road \& Transport Research, 10(3), 84-98.

58. Guo, X. \& Black, J. (2000). Traffic flow causing severance on urban street'. In Traffic and Transportation Studies (2000) (pp. 628-35). American Society of Civil Engineers.

59. Halsted, E. L. (1999). Roads, social severance and elderly pedestrians: A Palmerston North pilot study. [Master thesis, Massey University].

60. Hamersma, M., Tillema, T., Sussman, J. \& Arts, J. (2014). Residential satisfaction close to highways: The impact of accessibility, nuisances and highway adjustment projects. Transportation Research Part A: Policy and Practice 59(Supplement C):106-21. doi: https://doi.org/10.1016/j. tra.2013.11.004.

61. Handy, S. L. (2003). Amenity and severance. In D. A. Hensher \& K. J. Button. (eds.) Handbook of Transport and the Environment. Vol. 4, Handbooks in Transport. Emerald Group Publishing Limited.

62. Handy, S. L., \& Niemeier, D. A. (1997). Measuring accessibility: An exploration of issues and alternatives. Environment and Planning A, 29(7) 1175-1194.

63. Hart, J., \& Parkhurst, G. (2011). Driven to excess: Impacts of motor vehicles on the quality of life of residents of three streets in Bristol UK. World Transport Policy \& Practice, 17(2), 12-30.

64. Helldin, J. O., Folkeson, L., Göransson, G, Van der Grift, E., Henningsson, M., Herrmann, M, Kjellander, P., Kunc, H., Nilsson M. E., Pouwels, R., Seiler \& A, Sjölund, A. (2010). Similar impacts, similar solutions? The effects of transport infrastructure on outdoor recreation and wildlife. In: Proceedings of the 2009 international conference on ecology and transportation (pp. 268-275). Center for Transportation and the Environment, North Carolina State University.

65. Héran, F. (1999). Methods of evaluation of severance effects of large infrastructures on cycle trips.' In Velo City '99. The 11th international bicycle planning conference. The bicycle crossing frontiers. Proceedings (pp. 515-519). Graz, Maribor.
66. Héran, F (2009). Des distances à vol d'oiseau aux distances réelles ou de I'origine des détours. Flux n 76-77(2). doi: https://doi.org/10.3917/flux. 076.0110.

67. Héran, F. (2011). La Ville Morcelée - Effets de Coupure En Milieu Urbain. Economica.

68. Hine, J. (1996). Pedestrian travel experiences: Assessing the impact of traffic on behaviour and perceptions of safety using an in-depth interview technique. Journal of Transport Geography, 4(3), 179-199.

69. Hine, J., \& Mitchell, F. (2003). Patterns and practices. Routledge.

70. Hine, J., \& Russell, J. (1993). Traffic barriers and pedestrian crossing behaviour. Journal of Transport Geography, 1(4), 230-239. https://doi. org/10.1016/0966-6923(93)90047-4

71. Hine, J. \& Russell, J. (1996). The impact of traffic on pedestrian behaviour-2. Assessing the Traffic Barrier on Radial Routes'. Traffic Engineering + Control 81-85

72. Ivehammar, P. (2008). Valuing in actual travel time environmental encroachment caused by transport infrastructure. Transportation Research Part D: Transport and Environment, 13(7), 455-461.

73. Jacobs, J. (1961). The curse of border vacuums. P. Ch 14 in Death and Life of American Cities. Random House.

74. Jarlebring, I., Persson, S., Lindqvist, E \& Eliasson, J. (2002). Beräkning Av Gångtrafikeffekter Vid Väginvesteringar - En Handledning. Report. Transek.

75. James, E., Tomlinson, P., \& Reid, S. (2004). Divided we fall. Surveyor., 191(5772), 22-23.

76. James, E., Millington, A. \& Tomlinson, P. (2005). Understanding Community Severance I. Views of Practitioners and Communities. Report. TRL Limited.

77. Johansson, M. (1998). Introduktion till Värdering Av Väganläggningars Miljöintrång. Report (VTI meddelande 836). VTI Statens väg-och transportforskningsinstitut.

78. Joyce, F. E., \& Williams, H. E. (1972). On assessing the environmental impact of urban road traffic. International Journal of Environmental Studies, 3(1-4), 201-207. https://doi.org/10.1080/00207237208709516

79. Kang, C. D., \& Cervero, R. (2009). From elevated freeway to urban greenway: Land value impacts of the CGC project in Seoul, Korea. Urban Studies, 46(13), 2771-2794. https://doi.org/10.1177/0042098009345166

80. Khreis, H., May, A. D., \& Nieuwenhuijsen, M. J. (2017). Health impacts of urban transport policy measures: A guidance note for practice. Journal of Transport \& Health, 6, 209-227. https://doi.org/10.1016/j.jth.2017.06. 003

81. King, R. J. (1978a). Social differentiation as a key to assessing the social effects of transport related changes. Report (no 83). ARRB Group Ltd.

82. King, R. J. (1978b). Social impact of transport related changes: A classification of residential areas. Report (AIR 268-1). Australian Road Research Board (ARRB)

83. King, R. J. (1982). Application of social impact assessment. Report (AIR 311-2). Australian Road Research Board (ARRB).

84. King, R. J. (1983). Some problems in assessing the social effects of transport related plans. Australian Road Research, 13(4), 271-284.

85. King, R. A. R., \& Blackmore, K. L. (2013). Physical and political boundaries as barriers to the continuity of social vulnerability. Applied Geography, 44, 79-87. https://doi.org/10.1016/j.apgeog.2013.07.011

86. Koorey, G. \& Chesterman, R. (2010). Assessing the environmental capacity of local residential streets.

87. Korner, J. (1979). Trafikanläggningars Barriäreffekter: 1. Problembeskrivning, Begreppsanalys Och Teoriansats - En Litteraturstudie. Report (1979:1). Chalmers Tekniska Högskola.

88. Lara, D. V. R., \& Rodrigues da Silva, A. N. (2019). Equity issues associated with transport barriers in a Brazilian medium-sized city. Journal of Transport \& Health, 14, 100582. https://doi.org/10.1016/j.jth.2019.100582

89. Lara, D. V. R., \& Rodrigues da Silva, A. N. (2020). Equity issues and the PeCUS index: An indirect analysis of community severance. Geo-Spatial Information Science. https://doi.org/10.1080/10095020.2020.1843373

90. Larouche, R. Mitra R. \& Waygood, E. O. W. (2020). Transport and physical wellbeing. In Transportation and children's well-being. (pp. 21-39) Elsevier.

91. Lassière, A. (1976). 6. severance. In The environmental evaluation of transport plans. Vol. 8. UK Department of Environment.

92. Lassière, A., \& Bowers, P. (1972). Studies on the Social Costs of Urban Road Transport (Noise and Pollution). OECD. 
93. Lee, T., \& Tagg, S. (1976). The social severance effects of major urban roads. In P. Stringer \& H. Wenzel (Eds.), Transportation planning for a better environment (pp. 267-281). Springer.

94. Levine, J, Grengs, J., Shen, Q. \& Shen, Q. (2012). Does accessibility require density or speed?: A comparison of fast versus close in getting where you want to go in U.S. metropolitan regions. Journal of the American Planning Association 78(2):157-72. doi: https://doi.org/10.1080/01944 363.2012.677119.

95. Loir, C. \& Icher, J. (1983). Les effets de coupure de voies routiers et autoroutieres en milieu urbain et periurbain. Report. CETUR Cete Bordeaux.

96. Maciorowski, M. M., \& Souza, J. C. (2018). Urban roads and non-motorized transport: The barrier effect and challenges in the search for sustainable urban mobility. Transportation Research Procedia, 33, 123-130.

97. Marsh, K. \& Watts, C. (2012). Literature review on community severance and social connectedness: Definitions, pathways and measurement Report. New Zealand Transport Agency. https://www.nzta.govt.nz/ assets/resources/literature-review-community-severance-social-conne ctedness/docs/literature-review-community-severance-social-conne ctedness-definitions-pathways-measurement.pdf

98. Marshall, W. E. \& McAndrews, C. A. (2016). Does the Livability of a Residential Street Depend on the Characteristics of the Neighboring Street Network? Report. University of Colorado Denver.

99. Meltofte, K. R. \& Nørby L. E. (2013). Vejen som barriere for fodgængere. In Artikler fra Trafikdage på Aalborg Universitet (Proceedings from the annual transport conference at Aalborg University). Aalborg.

100. Miller, J. (2018, February 21). Roads to nowhere: How infrastructure built on American inequality. The Guardian. https://www.theguardian.com/ cities/2018/feb/21/roads-nowhere-infrastructure-american-inequality

101. Mindell, J. \& Anciaes, P. (2020). Transport and community severance'. In Advances in transportation and health (pp. 175-196). Elsevier.

102. Mindell, J., \& Karlsen, S. (2012). Community severance and health: What do we actually know? Journal of Urban Health, 89(2), 232-246. https:// doi.org/10.1007/s11524-011-9637-7

103. Mindell, J., Rutter, H., \&Watkins, S. (2011). Urban transportation and human health. In J. O. Nriagu (Ed.), Encyclopedia of environmental health (1st ed., pp. 578-589). Elsevier.

104. Mindell, J., Vaughan, L., Jones, P., Haklay, M., Groce, N., Scholes, S., Anciaes, P., Boniface, S., Stockton, J., Dhanani, A. \& Tarkhanyan, L. (2017). Street mobility project: Toolkit. Report. UCL. http://discovery.ucl.ac.uk/ 1540726/

105. Mitchell, R., \& Lee, D. (2014). Is there really a "Wrong side of the tracks" in urban areas and does it matter for spatial analysis? Annals of the Association of American Geographers, 104(3), 432-443. https://doi.org/10.1080/ 00045608.2014 .892321

106. Monzon, A., Vega, L. A. \& Pardeiro, A. M. (2005). Assessment of the effects of improving the madrid inner ring road to a more balanced and sustainable metropolitan mobility. In Proceedings of ETC 2005. Strasbourg.

107. Moon, A. E. (1975). Urban railroad relocation: Nature and magnitude of the problem. Report. Stanford Research Institute.

108. Mouette, D. \& Waisman, J. (2004). Proposta de uma metodologia de avaliação do efeito barreira. Revista dos Transportes Públicos Ano 26.

109. Nimegeer, A., Thomson, H., Foley, L., Hilton, S., Crawford, F., \& Ogilvie, D. (2018). Experiences of connectivity and severance in the wake of a new motorway: Implications for health and well-being. Social Science \& Medicine, 197, 78-86. https://doi.org/10.1016/j.socscimed.2017.11.049

110. Noonan, D. S. (2005). Neighbours, barriers and urban environments: Are things "different on the other side of the tracks"? Urban Studies, 42(10), 1817-1835. https://doi.org/10.1080/00420980500231720

111. OECD. (1973). Effects of Traffic and Roads on the Environment in Urban Areas. OECD.

112. Ogilvie, D., Mitchell, R., Mutrie, N., Petticrew, M., \& Platt, S. (2010). Shoe leather epidemiology: Active travel and transport infrastructure in the urban landscape. International Journal of Behavioral Nutrition and Physical Activity, 7(43), 1-15.

113. Palau, E. J. A., Asensi, M. H. \& Aymerich, A. T. (2016). Morphologic model of urban growth induced by the railway system infrastructure. Case study for 25 Catalan cities. Scripta Nova 20.

114. Peeters, M., \& Elffers, H. (2010). Do physical barriers affect urban crime trips? The effect of a highway, a railroad, a park or a canal on the flow of crime in the Hague. Crime Patterns and Analysis, 3(1), 38-49.
115. Poole, A. (2003). 'Measuring accessibility in scheme appraisal. In Proceedings of the European transport conference 2003. Strasbourg.

116. Quigley, R., \& Thornley, L. (2011). Literature review on community cohesion and community severance: Definitions and indicators for transport planning and monitoring. Quigley and Watts Ltd.

117. Rajé, F. (2004). Engineering social exclusion poor transport links and severance. Municipal Engineer, 157(ME4), 267-273.

118. Ratcliffe, J. (2003). Suburb Boundaries and Residential Burglars. Report (246). Australian Institute of Criminology.

119. Read, M. D. \& Cramphorn, B. (2001). Quantifying the Impact of Social Severance Caused by Roads. Report (no 201). Transfund New Zealand.

120. Ribalaygua, C., \& Perez-Del-Caño, S. (2019). Assessing spatial planning strategy in high-speed rail station areas in Spain (1992-2018): towards a sustainable model. European Planning Studies, 27(3), 595-617.

121. Rintoul, D. (1995). Social cost of transverse barrier effects. Report. Ministry of Transportation \& Highways, Planning Services Branch.

122. Russell, J. \& Hine, J. (1996). The impact of traffic on pedestrian behaviour-1. Measuring the Traffic Barrier. Traffic Engineering + Control 16-18.

123. Rytwinski, T., \& Fahrig, L. (2012). Do species life history traits explain population responses to roads? A meta-analysis. Biological Conservation, 147(1), 87-98. https://doi.org/10.1016/j.biocon.2011.11.023

124. Sælensminde, K. (2002). Gang-og sykkelvegnett i norske byer: nytte-kostnadsanalyser inkludert helseeffekter og eksterne kostnader av motorisert vegtrafikk. Report (567/2002). Transportøkonomisk institutt.

125. Sauter, D., \& Huettenmoser, M. (2008). Liveable streets and social inclusion. Urban Design International, 13(2), 67-79. https://doi.org/10.1057/ udi.2008.15

126. Shergold, I. \& Parkhurst, G. (2009). The Treatment of Social and Distributional Impacts in Appraisal and Evaluation - Literature Review - Final Report. Report. University of the West of England, Bristol.

127. Sherwood, P.T. (1971). Roads, traffic and the environment. Roads Road Constr, 49(581), 137-142.

128. Soguel, N. C. (1995). Costing the traffic barrier effect: A contingent valuation survey. Environmental and Resource Economics, 6(3), 301-308.

129. Tate, F. N. \& Mara, K. (1997). An evaluation frame work for social severance. In IPENZ annual conference 1997, proceedings of: engineering our nation's future; volume 1; papers presented in the technical programme of the IPENZ annual conference held in Wellington, February 7-10, 1997. Institution of Professional Engineers New Zealand.

130. Tate, F. N. (1997). Social Severance. Report (no 80). Transit New Zealand.

131. Tavares, L., Andrade, M., \& Maia, M. L. (2017). Urban impacts due to barrier effect caused by road duplication: The case of Goianinha/RN in Brazil. In Transportation research procedia (vol. 25, pp. 4637-4648).

132. The Countryside Agency \& ICE. (2002). Rural Routes and Networks Creating and Preserving Routes That Are Sustainable, Convenient, Tranquil, Attractive and Safe. Report. The Countryside Agency \& ICE.

133. Thomas, E. N. \& Schofer, J. L. (1970). Strategies for the Evaluation of Alternative Transportation Plans. Report (no 96). Northwestern University.

134. Tirachini, A. (2015). Probability distribution of walking trips and effects of restricting free pedestrian movement on walking distance. Transport Policy, 37, 101-110. https://doi.org/10.1016/j.tranpol.2014.10.008

135. Transportation Alternatives. (2006). Traffic's Human Toll - A Study of the Impacts of Vehicular Traffic on New York City Residents. Transportation Alternatives.

136. Vigar, G. (1999). Transport for people. In: Greed C (ed) Social town planning: Planning and social policy. Taylor and Francis.

137. van Wee, B. (2012). How suitable is CBA for the ex-ante evaluation of transport projects and policies? A discussion from the perspective of ethics. Transport Policy, 19, 1-7. https://doi.org/10.1016/j.tranpol.2011. 07.001

138. van Eldijk, J., Gil, J., Kuska, N., \& Sisinty Patro, R. (2020). Missing linksQuantifying barrier effects of transport infrastructure on local accessibility. Transportation Research Part D: Transport and Environment, 85, 102410. https://doi.org/10.1016/j.trd.2020.102410

139. van Essen, H., Schroten, A., Otten, M., Sutter, D., Schreyer, C., Zandonella, R., Maibach, M. \& Doll, C. (2011). External costs of transport in Europe. Report. CE Delft. http://ecocalc-test.ecotransit.org/CE_Delft_4215_ External_Costs_of_Transport_in_Europe_def.pdf 
140. Warr, M. (2000). Fear of Crime in the United States: Avenues for Research and Policy. In Criminal justice 2000: Measurement and analysis of crime and justice. Vol 4. National Institute of Justice

141. Watkiss, P., Brand, C., Hurley, F., Pilkington, A., Mindell, J., Joffe, M., \& Anderson, R. (2000). Informing Transport Health Impact Assessment in London. Report. Research \& Development directorate, NHS Executive London.

142. Wegen, H. B. van \& van der Voordt, D. J. (1991). 'Sociale veiligheid en gebouwde omgeving: Theorie, empirie en instrumentontwikkeling'. [Dissertation, Delft University of Technology].

143. Wiki, J., Kingham, S., \& Banwell, K. (2018). Re-working appleyard in a low density environment: An exploration of the impacts of motorised traffic volume on street Livability in Christchurch, New Zealand'. World Transport Policy \& Practice, 24(1), 60-68.

144. Xiao, L., Ruiter, S., Liu, L., Song, G., \& Zhou, S. (2021). Burglars blocked by barriers? The impact of physical and social barriers on residential burglars'Target Location Choices in China. Computers, Environment and Urban Systems. https://doi.org/10.1016/j.compenvurbsys.2020.101582

\section{Publisher's Note}

Springer Nature remains neutral with regard to jurisdictional claims in published maps and institutional affiliations.

\section{Submit your manuscript to a SpringerOpen ${ }^{\odot}$ journal and benefit from:}

- Convenient online submission

- Rigorous peer review

- Open access: articles freely available online

- High visibility within the field

- Retaining the copyright to your article

Submit your next manuscript at $\boldsymbol{\nabla}$ springeropen.com 